\title{
FAMILY OWNERSHIP AND TAX AVOIDANCE: AN ANALYSIS OF FOREIGN RELATED PARTY TRANSACTIONS AND DIVIDEND PAYMENTS
}

\author{
Nuritomo \\ Universitas Atma Jaya Yogyakarta \\ Sidharta Utama \\ Universitas Indonesia \\ Ancella A, Hermawan* \\ Universitas Indonesia
}

\begin{abstract}
This paper aims to investigate the effect of shareholder tax burden on related party transactions (RPTs) and dividend payments in Indonesia. The paper also investigates the moderating effect of family ownership on the relationship between shareholder tax burden, RPTs and dividend payments. The study uses 451 firm-year observations comprising hand-collected data for the period 2010-2015. The results suggest that a high shareholder tax burden has a positive effect on RPTs and a negative effect on dividend payments. This indicates that companies engage in tax avoidance through dividend minimization and RPTs. When faced with a high tax burden, companies tend to reduce dividends and increase their RPTs in a bid to reduce their tax burden. This research also shows that the positive effect of shareholder tax burden on RPTs is weakened with greater family ownership and that the negative effect of shareholder tax burden on dividend payments is strengthened by greater family ownership. This proves that Indonesian family firms tend to engage in tax avoidance through the use of dividend mechanisms as opposed to RPTs.
\end{abstract}

Keywords: Tax avoidance; Tax burden; Family ownership; Related party transaction; Dividend.

\section{INTRODUCTION}

In 2016, Indonesian government has implemented a Tax Amnesty program aimed at returning the money of Indonesians in foreign countries. Data recorded by the Indonesian Government show that Indonesian citizens in foreign countries have assets totaling in excess of Rp 11,000 trillion. This indicates that many companies in Indonesia are conducting tax avoidance by taking advantage of international tax loopholes.

\footnotetext{
* Corresponding author: Department of Accounting, Universitas Indonesia, Kampus FEB UI Depok, 16424, Indonesia. Phone +62217863558. Email: ancella_hermawan@yahoo.com
} 
Fama \& French (2001) reported that there had been a significant decrease in dividends and a shift from direct dividend payments to share repurchases. On the other hand, Zhang (2008) found there had been a steady increase in RPTs. Economic growth has led to an increase in the number of RPTs, and it is estimated that as many as two-thirds of transactions are RPTs linked to transfer pricing schemes, especially in developing countries (PriceWaterhouseCoopers, 2011). Su, Fung, Huang, and Sen (2014) found evidence that RPTs are negatively related to dividend payments, thus indicating that both mechanisms of tax avoidance are still being conducted.

As a developing country with a relatively weak judicial system, Indonesia faces greater challenges in dealing with corporate tax avoidance (OECD, 2013). Since family ownership tends to be the dominant type of ownership structure among Indonesian corporations (Claessen, Djankov, \& Lang, 2000), this may also have an effect on corporate tax avoidance practices. Nevertheless, the findings reported by studies on the tax avoidance practices conducted by family-owned corporations have remained inconclusive. For example, Chen, Chen, Cheng, \& Shevlin (2010), found that US family firms tend to reject tax avoidance practices, while Sari \& Martani (2010), showed that Indonesia family-owned companies tend to favor tax avoidance. Differences in conflicts of interest, investment time horizons, and investment goals may affect the methods of tax avoidance used by family firms.

In studies on the relationship between family ownership and tax avoidance, researchers have often focused on the total corporate tax burden by using only effective tax rates and book-tax differences as the measure (Desai \& Dharmapala, 2006). In the present study, tax avoidance practices are indicated by the relationship between shareholder tax burden, RPTs, and dividend payments. Evidence of tax avoidance practices will be indicated by a positive relationship between shareholder tax burden and RPTs, and a negative relationship between shareholder tax burden and dividend payments. This study aims to examine whether shareholder tax burden influences the level of RPTs and dividend payments in the companies, and examine the effect of family ownership on tax avoidance practices through foreign RPTs and dividend payments.

Graham (2003) states that a better understanding is needed of whether corporate actions are affected by investor-level taxes. While investor-level taxes may not surface as the primary driver of payout policy across studies, our paper attempts to provide evidence that investor-level taxes are important for payout decisions. Both corporate tax avoidance and dividend taxes provide incentives regarding the amount of tax a firm pays on its profits, and are potentially of first-order importance in other strategic decisions (Allen \& Michaely, 2003). Dividend tax alters incentives for managers, corporations, and shareholders when making decisions about investment opportunities, capital structures, and dividend policies, as well as their tax strategies (Amiram, Andrew, \& Mary, 2019).

In this research, we use the variable shareholder tax burden. This research employs the term shareholder tax burden in order to illustrate the difference from the statutory tax rate or dividend tax rate. The shareholder tax burden refers to all of the tax expenses that shareholders have to pay (including corporate tax and dividend tax) if they receive a dividend from the corporation. In the Indonesian tax system, corporate earnings are taxed at the firm level and then again at the shareholder level when they are distributed as dividends (classical tax system). Therefore, costly tax planning, designed to reduce shareholders' taxes, increases after-tax cash flows to both the corporation and shareholders. In the Indonesian classical tax system, a dollar saved through 
corporate tax avoidance reduces the overall tax burden, increases the after-tax cash flows to shareholders, and provides managers with an incentive to avoid taxes on shareholders' behalf (Amiram et al., 2019). The classical tax system thus incentivizes managers to engage in corporate tax avoidance in order to return more after-tax cash to shareholders.

Research has shown that there are non-tax benefits to be gained by paying dividends, such as investor preferences for dividends (Gordon, 1963), controlling agency problems (Jensen, 1986), or signaling performance (Bhattacharya, 1979). A manager will fix the dividend policy at the point at which the marginal benefit of an extra dollar of dividends equals the marginal tax cost. Reductions in the dividend tax rate can lower the required rate of return and lead to greater investment and higher dividend payouts (Hanlon \& Heitzman, 2010). Based on this view, reductions in dividend tax rates increase both share values and the investment incentives for dividend-paying firms because they lower the pre-tax required rate of return. In addition, a reduction in the tax lowers the marginal cost of paying dividends, thus leading to higher dividend payouts. These so-called efficiency consequences of dividend taxation lend support to proposals to reduce or eliminate dividend taxation because, if eliminated, there would be fewer distortions (Hanlon \& Heitzman, 2010). Hanlon \& Hoopes (2014) found that corporations respond to individual-level tax rate changes and act with the aim of maximizing shareholder wealth. Companies thus engage in tax avoidance in a bid to increase shareholder wealth via the minimization of shareholder taxes (Hanlon \& Hoopes, 2014).

In the event that the tax burden incurred by shareholders on dividends is high, companies can act to mitigate this by minimizing the dividend payments (Blouin, Ready, \& Shackelford, 2011; Hanlon \& Hoopes, 2014). However, it is possible for an operating company to store the cash it pays to reduce a free cash flow problem in a holding company at zero tax costs, until such time as the owner needs the cash (Berzins, Bøhren, \& Stacescu, 2019). Companies can also avoid shareholder dividend tax by entering into RPTs through transfer pricing schemes in order to obtain tax benefits. By conducting foreign RPTs at different tax rates, shareholders can enjoy the benefits of marginal tax rates. In Indonesian income tax law, dividend payments are not strictly regulated. Unlike RPTs, for which there are strict rules and reporting requirements, different choices can be made with regard to tax avoidance through dividend minimization and RPTs.

The main strength of this study lies in its focus on the different law regarding dividends in Indonesia, compared to the laws in other countries. In Indonesia, dividend taxes apply only to individual and corporate taxpayers with ownership of less than 25 percent. The dividends received by resident individual and corporate taxpayers are subject to final income tax rates of $10 \%$ and $15 \%$, respectively. Meanwhile, the dividend tax rate applied to non-resident taxpayers is $20 \%$. These differences in tax rates enable this study to examine the different dividend tax liabilities among companies' shareholders, depending on the ownership structure of each company. The payment of dividends in Indonesia is subject to double taxation. This results in a high shareholder tax burden if the company makes dividend payments and thus means companies tend to decrease their dividend payments as a means of avoiding the taxes that must be paid.

Various studies have shown that family firms use RPTs to transfer corporate wealth to themselves and harm minority shareholders (Jian \& Wong, 2004). These findings support the concept of tunneling (Johnson, LaPorta, Lopez-de-Silanes, \& Shleifer, 2000), whereby family firms have been shown to exhibit a preference for engaging in RPTs as a means of transferring company assets to 
themselves. Therefore, family firms are able to pay fewer dividends than non-family firms due to the fact they have received cash flow through RPTs. As the majority shareholder and controller of the firm, the family can easily influence management policies, especially in family firms, where the management are often members of the controlling family. These circumstances provide a great opportunity for expropriation, which may be one of the methods used by majority shareholders to gain cash and avoid dividend tax through RPTs.

The present study contributes significant insights into the role of family ownership in tax avoidance practices. The unique state of the dividend tax system in Indonesia provides a gap for researchers to explore the extent of tax avoidance using the individual level of taxes with the shareholder tax burden. Indonesian companies doing more foreign RPTs and minimization their dividend payments to shareholders as a tax avoidance strategy. In this case, the researchers were able to show the differences in the role of family ownership in the case of high-risk tax avoidance practices through RPTs and also with respect to low-risk avoidance through the minimization of dividend payments.

This study makes several contributions. From a theoretical viewpoint, this research contributes to the empirical evidence on the relationship between shareholder tax burden and foreign RPTs. Previous studies have often focused only on RPTs without considering the tax elements. RPTs will only provide tax benefits if they are conducted among companies with different tax rates. Second, this study uses the measurement of shareholder tax burden by adjusting it appropriately to Indonesian tax laws. The calculations used in the study employ the Indonesian tax system that results in double taxation. Third, since the Indonesian tax system imposes different dividend tax rates on companies, depending on their ownership structures, the researchers were able to provide stronger evidence of the relationship between dividend tax burden and dividend payments. Previous studies on dividend taxes have only used dividend tax system approaches. Fourth, this study show family firm tax avoidance from two mechanism in two risk condition: RPTs and Dividend.

The remainder of this paper is structured as follows: Section 2 reviews the relevant literature and outlines the hypothesis development; Section 3 describes the sampling method, research design, and research methods; Section 4 presents and discusses the findings of this study, and Section 5 concludes the paper.

\section{LITERATURE REVIEW AND HYPOTHESIS DEVELOPMENT}

\subsection{Agency Theory and Corporate Ownership in Indonesia}

Indonesian firms are characterized by majority ownership is concentrated in the hands of the largest block holder (Siregar \& Utama, 2008). This statistic supports the expropriation hypothesis in Shleifer \& Vishny (1997), who argue that once the ownership level moves beyond a certain point, the large owners gain almost full control and prefer to use firms to generate private benefits of control that are not shared with minority shareholders. When corporations are effectively controlled by large shareholders, their policies may result in the expropriation of minority shareholders. There may be numerous conflicts of interest between large and small shareholders, 
yet these may include controlling shareholders enriching themselves by not paying out dividends or shifting profits to other companies they control (Claessens et al., 2000).

Arifin (2003) found that in his sample of publicly listed firms in Indonesia, family-controlled firms, state-owned firms, or institutionally controlled firms experienced fewer agency problems than publicly controlled firms or firms with no controlling shareholders. He suggests that family-owned firms face fewer agency problems as there is less conflict between the principal and agent. There is likely to be an expropriation of minority shareholders if any portion of the capital is invested in public firms, even if the company is controlled by one family. This happens because public firms are exploited by their owners who use them to collect funds from the public, which are in turn transferred to other firms in the business group (Siregar \& Utama, 2008).

Agency theory suggests that family firms may either mitigate or exacerbate agency problems. Some have argued that the family firm is one of the most efficient forms of organizational governance and it is even used as the zero agency-cost base by finance researchers (Ang, Coles, \& Wuh-Lin, 2000). Families are widely believed to have greater incentives to monitor managers than other large shareholders or corporations with widely dispersed ownerships (Anderson \& Reeb, 2003). Indeed, LaPorta, Lopez-de-Silanes, \& Shleifer (1999) indicated that families are almost always involved in the management of the firm, which may result in greater alignment between the interests of shareholders and managers. Others, however, have argued that families also have a powerful incentive to expropriate wealth from minority shareholders (Faccio, Lang, \& Young, 2001) arguments imply that Type II agency problems might be more prevalent in family firms. Family investors usually maintain their ownership stakes for several generations, have a majority of their wealth invested in a single firm, and often serve as senior executives in the firm (Mackie, 2001). Demsetz \& Lehn (1985) suggested that families influence firm policies to meet their interests, thereby drawing limited resources from profitable investments. Faccio et al. (2001) reported that family ownership results in greater transactions between companies owned by the same family and thereby facilitates the expropriation of minority shareholder wealth.

Concentrated family ownership means that block shareholders can influence management to pursue the types of corporate action that will benefit them. One such corporate activity is the minimization of dividend payments and RPTs to avoid a high shareholder tax burden. Minimizing dividend payments will benefit shareholders and help ensure companies can provide a high cash flow for their shareholders and also help them in achieving their ultimate goal of maximizing shareholder wealth. RPTs are carried out by companies to provide high returns on shareholder investments and avoid the tax burdens that shareholders face if they receive dividends.

\subsection{Hypothesis Development}

\section{Tax Avoidance, Related Party Transactions, and Dividends}

Through RPTs such as asset transfer and transfer pricing, shareholders may obtain exclusive personal benefits in the form of greater profit or cash and tax savings (Su et al., 2014). Indonesia's system of double taxation levied on retained earnings (corporate tax) and dividend tax means that greater amounts of tax are paid in Indonesia compared to other countries (Alzahrani \& Lasfer, 2012). A high tax burden will increase the company's incentives to engage in tax avoidance. RPTs through international transfer pricing are one of the mechanisms used by multinational 
corporations to avoid taxes. This technique is employed by companies based in countries with high tax rates to shift profits to companies in countries with low tax rates (PriceWaterhouseCoopers, 2011). Sun (1999) found that Chinese companies tend to sell goods abroad more cheaply and buy more expensive quantities, then record their tax avoidance behavior in the form of RPTs. The same thing has occurred in Russia, which has a relatively high tax rate. Baker (2005) also identified the use of RPTs by Russian companies in an effort to avoid taxation. Hence, the first hypothesis of this study is:

\section{H1: Shareholder tax burden has a positive effect on related party transactions.}

Tax preference theory states that tax on dividends will influence the behavior of shareholders. A high dividend tax burden will encourage companies to reduce their cash dividend payments (Brennan, 1970; Farrar \& Slewyn, 1967). Alzahrani \& Lasfer (2012) found that countries with classical tax systems tend to pay lower dividends compared to countries with an imputation tax system. Chen \& Gupta (2011) found that the effect of credit from imputation had a positive effect on the delivery of dividends from affiliates abroad. Foley, Hartzell, Titman, \& Twite (2007) found that tax costs resulted in companies in the United States holding more money abroad to avoid paying high taxes. Desai, Foley, \& Hines (2001) estimated that a one percent decrease in the repatriation tax rate related to a one percent increase in the amount of foreign dividends deposited. Overall, this research shows that high taxes will affect the company's dividend payments. Many studies have proved that a decrease in dividend taxes increases dividend payments through special dividends (Hanlon \& Hoopes, 2014). Wang \& Guo (2011) found that dividend tax cuts cause companies to increase their dividend payments. Blouin et al. (2011) also produced the same results. Their studies show that taxes affect the dividend payment behavior of companies. Hence, the second hypothesis of this study is:

H2: Shareholder tax burden has a negative effect on dividend payments.

\section{Family Ownership, Tax Avoidance, and Risk}

The family owned companies problems usually relate to conflicts of interest between the majority and minority shareholders, as opposed to conflicts between the management and principal (Anderson \& Reeb, 2003). This is known as the Type II agency problem and often occurs in companies with concentrated ownership. RPTs are one of the most frequently used methods of expropriation by majority shareholders and can at times adversely affect the minority shareholders. Zhuang, Edwards, Webb, \& Capulong (2000) stated that there are two possible effects of concentrated ownership: effective oversight role for management, or expropriate minority shareholders through RPTs.

Firms engaging in corporate tax avoidance face potentially significant costs and risks like increased legal and transaction costs (Rego \& Wilson, 2012), hostility toward the firm, including reputational damage among its various stakeholders (Lanis \& Richardson, 2012). If tax avoidance is detected and the tax position is found to be unsupported, it can result in further financial penalties as well as the potential for increased damage to the firm's reputation (Desai \& Dharmapala, 2006; Hanlon \& Slemrod, 2009; Lanis \& Richardson, 2012). Managers implementing tax avoidance strategies are also personally exposed to the risk of penalties and fines, along with damage to their reputations. Therefore, in order to encourage managers and firms to engage in tax avoidance, either 
the benefits gained from tax avoidance need to significantly exceed the potential costs, or the costs need to be insignificant. It is also likely that the costs and benefits of corporate tax avoidance will differ somewhat across firms as a reflection of varying firm-level characteristics and tax avoidance techniques (McClure, Lanis, Wells, \& Govendir, 2018). Family owners are more concerned with the potential penalty imposed, because of their much larger equity ownership and their much longer investment horizons also more concerned with the negative publicity and the potential damage to the long-term firm value (Chen et al., 2010). As a result, it is suspected that family-owned companies will choose not to engage in tax avoidance through RPTs as the practice, along with that of transfer pricing, has become a main topic of attention for governments in both Indonesia and across the world. Hence, the third hypothesis of this study is:

H3: The positive effect of shareholder tax burden on related party transactions is weakened with greater family ownership.

Family ownership in the company will reduce the Type I agency problem between management and shareholders. This will lead to the dividend function as the company's internal control is reduced and the free cash flow that can be used as an expropriation becomes irrelevant for family firms. Under these conditions, family firms are able to pay greater attention to tax avoidance than dividend payments. On the other hand, family ownership of the firm will also have an impact on Type II agency conflicts. This can lead to family firms conducting various RPTs to avoid high tax payments if the company distributes dividends.

Unlike risky RPTs that are strictly controlled by tax regulation, dividend payments have lower tax risks. In addition, family-owned companies will generally have strong management controls aimed at minimizing agency problems. Consequently, the function of dividends in terms of monitoring the company becomes weaker. With good control, family ownership can minimize the possibility of free cash flow expropriation being undertaken by management if dividends are not distributed. Therefore, a family-owned company will pay greater attention to tax avoidance through dividend payments. Hence, the fourth hypothesis of this study is:

H4: The negative effect of shareholder tax burden on dividend payments is strengthened with greater family ownership.

\section{METHODS}

\subsection{Sampling Method}

The population of this study comprised all non-financial companies listed on the Indonesia Stock Exchange (IDX) during the period 2010 to 2015. The year 2010 was chosen as the beginning of the period as the issuance of Indonesian Law number 36 of 2008. The change had implications with regard to the amount of corporate income tax and dividend tax that companies pay. The year 2015 was chosen as the final year in the period under study because 2016 saw a tax amnesty policy in Indonesia in which all companies could declare their assets in return for amnesty from sanctions using 2015 financial data. This research used only data from Indonesia because Indonesia has several tax rates for dividends, depending on the firm's capital structure. This advantage means the research can analyze dividend tax between companies. Also excluded from the sample were 
companies that did not engage in RPTs or experience corporate actions such as mergers and acquisitions. After selecting the companies for inclusion in the sample, a total sample size of 451 firm-years was finally obtained.

Table 1: Sample Selection

\begin{tabular}{lc}
\hline \hline Criteria & Sample Amount \\
\hline Companies Listed on IDX 2010-2015 & 2,424 \\
Financial Companies & $(396)$ \\
Companies without Foreign RPTs & $(1,563)$ \\
Data Outliers & $(10)$ \\
\hline Final Sample & $\mathbf{4 5 1}$ \\
\hline \hline
\end{tabular}

\subsection{Variables and Measurement}

Following La Porta et al. (1999), this study used the family ownership variable (FAM $\left.\mathrm{F}_{\mathrm{it}}\right)$ with a family ownership of more than 20 percent as the controlling interest. A company would be given the value " 1 " if the family that was the majority shareholder owned more than 20 percent of the company's shares, and "0" otherwise. Shareholder tax burden $\left(\mathrm{TAX}_{\mathrm{it}}\right)$ was measured by using a combination of corporate tax rate and the effective tax rate on dividends (double taxation). The effective tax rate on dividends was calculated using a weighted average dividend tax rate for the shareholder based on the type and amount of ownership. Company A, for example, which has $20 \%$ of its shares owned by Company B, $20 \%$ owned by Mr. X, and $60 \%$ owned by foreign investors, will have a shareholder tax burden $\left(\mathrm{TAX}_{\mathrm{it}}\right)$ of $37.75 \%$. The rate is derived from (corporate tax rate $+(1$-corporate tax rate) $x$ dividend tax rate). For this sample, the calculation is thus $((25 \%)+(75 \% \times((20 \% \times 15 \%)+(20 \% \times 10 \%)+(60 \% \times 20 \%)))$. The $25 \%$ is Indonesia's corporate tax rate, and $75 \%$ is the after-tax retained earnings that are subject to dividend tax.

Following Jacob (1996), the related party transaction ( $\mathrm{RPT}_{\mathrm{it}}$ ) was measured by the amount of foreign related party sales $\left(\mathrm{RPTS}_{\mathrm{it}}\right)$, the amount of foreign related party purchases $\left(\mathrm{RPTP}_{\mathrm{it}}\right)$, the amount of foreign related party accounts payable $\left(\mathrm{RPTL}_{\mathrm{it}}\right)$, and the amount of foreign related party accounts receivable $\left(\mathrm{RPTA}_{\mathrm{it}}\right)$ scaled by total assets. Following Yeh, Shu, \& Su (2012) company size (ASSET ${ }_{i t}$ ) was measured by using the natural logarithm of total assets, while the company's leverage rate $\left(\mathrm{DER}_{\mathrm{it}}\right)$ was measured using the debt to equity ratio (DER). Following Fama and French (2001), company growth opportunity $\left(\mathrm{GROWTH}_{\mathrm{it}}\right)$ was measured by the percentage of total asset growth. Following Lanis \& Richardson (2012) profitability $\left(\mathrm{ROA}_{\mathrm{it}}\right)$ was measured using earnings before taxes to the total assets ratio. Corporate governance $\left(\mathrm{CG}_{\mathrm{it}}\right)$ was measured using the ASEAN Corporate Governance Scorecard checklist.

\subsection{Research Design}

In order to test the hypotheses of this study, the following formulas were used:

$$
\begin{array}{ll}
\mathrm{RPT}_{\mathrm{it}}= & \beta_{0}+\beta_{1} \mathrm{TAX}_{\mathrm{it}}+\beta_{2} \mathrm{ROA}_{\mathrm{it}}+\beta_{3} \mathrm{DER}_{\mathrm{it}}+\beta_{4} \mathrm{GROWTH}_{\mathrm{it}}+\beta_{5} \operatorname{Ln}(\mathrm{ASSET})_{\mathrm{it}}+\beta_{6} \mathrm{CG}_{\mathrm{it}}+\varepsilon_{\mathrm{it}} \\
\mathrm{DPR}_{\mathrm{it}}= & \beta_{0}+\beta_{1} \mathrm{TAX}_{\mathrm{it}}+\beta_{2} \mathrm{ROA}_{\mathrm{it}}+\beta_{3} \mathrm{DER}_{\mathrm{it}}+\beta_{4} \mathrm{GROWTH}_{\mathrm{it}}+\beta_{5} \operatorname{Ln}(\mathrm{ASSET})_{\mathrm{it}}+\beta_{6} \mathrm{CG}_{\mathrm{it}}+\beta_{7} \mathrm{FORG}_{\mathrm{it}}+ \\
\varepsilon_{\mathrm{it}}
\end{array}
$$




$$
\begin{aligned}
\mathrm{RPT}_{\mathrm{it}}= & \beta_{0}+\beta_{1} \mathrm{TAX}_{\mathrm{it}}+\beta_{2} \mathrm{ROA}_{\mathrm{it}}+\beta_{3} \mathrm{DER}_{\mathrm{it}}+\beta_{4} \mathrm{GROWTH}_{\mathrm{it}}+\beta_{5} \operatorname{Ln}\left(\mathrm{ASSET}_{\mathrm{it}}+\beta_{6} \mathrm{CG}_{\mathrm{it}}+\beta_{7} \mathrm{FAM}_{\mathrm{it}}\right. \\
& +\beta_{8} \mathrm{TAX}_{\mathrm{it}}{ }^{*} \mathrm{FAM}_{\mathrm{it}}+\varepsilon \mathrm{cit} \\
\mathrm{DPR}_{\mathrm{it}}= & \beta_{0}+\beta_{1} \mathrm{TAX}_{\mathrm{it}}+\beta_{2} \mathrm{ROA}_{\mathrm{it}}+\beta_{3} \mathrm{DER}_{\mathrm{it}}+\beta_{4} \mathrm{GROWTH}_{\mathrm{it}}+\beta_{5} \operatorname{Ln}\left(\mathrm{ASSET}_{\mathrm{it}}+\beta_{6} \mathrm{CG}_{\mathrm{it}}+\beta_{7} \mathrm{FORG}_{\mathrm{it}}\right. \\
& +\beta_{8} \mathrm{FAM}_{\mathrm{it}}+\beta_{9} \mathrm{TAX}_{\mathrm{it}} * \mathrm{FAM}_{\mathrm{it}}+\varepsilon \mathrm{cit}
\end{aligned}
$$

Model 1 was used to test hypothesis 1 , expected the value of $\beta_{1}$ to be greater than $0\left(\beta_{1}>0\right)$, meaning that shareholder tax burden positively affects RPTs. The second hypothesis was tested using Model 2 with the expected value of $\beta_{1}<0$, meaning shareholder tax burden negatively affects the dividend payments of the company. Model 3 was used to test Hypothesis 3 with the expected value of $\beta_{8}$ $<0$, meaning there is a lower positive relationship between shareholder tax burden and RPTs in family firms. Finally, the fourth hypothesis would be accepted if in Model 4 the value of $\beta_{9}$ was less than $0\left(\beta_{9}<0\right)$, thereby indicating there is a higher negative relationship between shareholder tax burden and dividend payments in family firms.

\section{RESULTS AND DISCUSSION}

\subsection{Descriptive Statistics}

Table 2: Descriptive Statistics

\begin{tabular}{lcccc}
\hline \hline \multicolumn{1}{c}{ VARIABLE } & Minimum & Maximum & Mean & Std. Deviation \\
\hline Ln_ASSET & 24.2611 & 33.3899 & 28.0471 & 1.7073 \\
GROWTH & -0.8914 & 2.6481 & 0.1730 & 0.2978 \\
ROA & 0.0005 & 2.6839 & 0.1123 & 0.1975 \\
DER & 0.0012 & 5.9638 & 1.0416 & 0.8004 \\
DPR & 0.0000 & 2.8265 & 0.3016 & 0.3296 \\
FAM & 0.0000 & 1.0000 & 0.5900 & 0.4924 \\
FORG & 0.0000 & 0.9900 & 0.4419 & 0.3325 \\
CG & 0.0000 & 0.8750 & 0.5195 & 0.1793 \\
TAX & 0.1039 & 0.3985 & 0.3255 & 0.0525 \\
RPTA & 0.0000 & 2.2903 & 0.0652 & 0.2105 \\
RPTL & 0.0000 & 1.9828 & 0.0633 & 0.1890 \\
RPTP & 0.0000 & 5.7513 & 0.1516 & 0.5538 \\
RPTS & 0.0000 & 13.6152 & 0.3047 & 1.3598 \\
\hline \hline
\end{tabular}

The total sample after omitting data outliers comprised 451 companies. The average growth of the sample was $17.0 \%$ with a profitability level of $11.23 \%$ and a DER of $104.15 \%$. The companies' dividend payments varied, with the highest at $283 \%$ and an average of $30 \%$ from profit. Companies with family ownership in excess of 20 percent accounted for $59 \%$ of the total sample, while those with foreign ownership accounted for $44.2 \%$. This high percentage of foreign-owned companies in the sample was due to the fact that most companies that conduct foreign RPTs are foreign-owned companies. The $\mathrm{CG}$ ratio had a value of $51.95 \%$, indicating that the sample of companies, on average, had good corporate governance. The shareholder tax burden ranged from $10.39 \%$ to $39.85 \%$ with an average of $32.55 \%$. The tax burden rate in $10.39 \%$ was related to a property company, calculated using final tax treatment of the property. The maximum tax burden of $39.85 \%$ showed a high tax rate resulting from double taxation (i.e., the corporate tax rate of $25 \%$ and the 
dividend tax rate of $14.85 \%$ ). The average tax burden of $32.55 \%$ suggested that the tax paid on dividends was relatively low, i.e., $7.55 \%$, assuming a corporate tax rate of $25 \%$. This indicates that companies in Indonesia tend to take preventive measures related to dividend taxes by using the ownership structures of the companies. Meanwhile, RPTs were dominated by RPTS with an average of $30.47 \%$, followed by RPTP at $15.16 \%$. The RPTA and RPTL) were approximately $6.52 \%$ and $6.33 \%$, respectively.

\subsection{Shareholder Tax Burden, RPT, and Dividend}

Table 3 contains the results of the Model 1 testing as evidence related to the first hypothesis of this study. The evidence proves consistent results for the four RPT measurement. The test results show that all measurements had a probability value of 0.0000 with a positive coefficient, thus proving that the tax burden positively affects the RPTs of the companies. This is in line with the domination of RPTS compared to other types of RPTs in the companies. A high corporate tax burden will result in a company conducting RPTs in order to avoid a high tax burden. Based on the results of the Model 1 testing, the first hypothesis is supported.

Table 3: Tax Avoidance and RPT

\begin{tabular}{lcccccccc}
\hline \multirow{2}{*}{ Variable } & \multicolumn{2}{c}{ RPTS } & \multicolumn{2}{c}{ RPTP } & \multicolumn{2}{c}{ RPTA } & \multicolumn{2}{c}{ RPTL } \\
\cline { 2 - 9 } & Coefficient & Prob & Coefficient & Prob & Coefficient & Prob & Coefficient & Prob \\
\hline C & -2.4126 & $0.0000^{* * *}$ & -0.7152 & $0.0000^{* * *}$ & -0.3216 & $0.0000^{* * *}$ & -0.2627 & $0.0000^{* * *}$ \\
TAX & $\mathbf{1 . 9 6 8 7}$ & $\mathbf{0 . 0 0 0 0 ^ { * * * }}$ & $\mathbf{0 . 9 7 5 7}$ & $\mathbf{0 . 0 0 0 0 ^ { * * * }}$ & $\mathbf{- 0 . 0 2 8 1}$ & $\mathbf{0 . 1 7 9 1}$ & $\mathbf{0 . 2 1 3 2}$ & $\mathbf{0 . 0 0 0 0 ^ { * * * }}$ \\
ROA & -0.0148 & 0.2502 & -0.0126 & $0.0071^{* * *}$ & -0.0181 & $0.0022^{* * *}$ & -0.0524 & $0.0008^{* * *}$ \\
DER & -0.0516 & $0.0000^{* * *}$ & 0.0139 & $0.0000^{* * *}$ & -0.0131 & $0.0000^{* * *}$ & 0.0209 & $0.0000^{* * * *}$ \\
GROWTH & -0.0660 & $0.0000^{* * *}$ & 0.0227 & $0.0268^{* *}$ & -0.0037 & $0.0191^{* *}$ & -0.0229 & $0.0000^{* * *}$ \\
Ln_ASSET & 0.0681 & $0.0000^{* * *}$ & 0.0150 & $0.0000^{* * *}$ & 0.0135 & $0.0000^{* * *}$ & 0.0072 & $0.0000^{* * *}$ \\
CG & -0.0195 & 0.5797 & 0.0506 & $0.0000^{* * *}$ & -0.0266 & $0.0259^{* *}$ & -0.0032 & 0.4381 \\
Adjusted R2 & \multicolumn{2}{c}{0.3220} & \multicolumn{2}{c}{0.4053} & 0.3088 & 0.4692 \\
Prob(F-stat) & \multicolumn{2}{c}{$0.0000^{* * *}$} & \multicolumn{2}{c}{$0.0000^{* * *}$} & $0.0000^{* * *}$ & $0.0000^{* * *}$ \\
\hline \hline
\end{tabular}

* significant at $10 \% ; * *$ significant at $5 \%$; *** significant at $1 \%$

Companies with a high shareholder tax burden tend to conduct a large number of RPTs for the purpose of shifting their profits. RPTs refer to the prices charged for the flow of goods and services among the member entities of companies that operate in different countries with different tax rates. Using RPTs, companies can shift profits from high-tax countries, such as Indonesia (due to its double taxation), to low-tax countries (such as tax havens) to take advantage of tax rate arbitrage. Thin capitalization generally refers to the heavy use of debt, rather than equity, as a source of finance. Since interest expense is tax-deductible, a higher level of debt creates a greater tax deduction. 
Table 4: Tax Avoidance, Dividend, and Family Ownership

\begin{tabular}{|c|c|c|c|c|}
\hline \multirow{2}{*}{ Variable } & \multicolumn{2}{|c|}{ DPR } & \multicolumn{2}{|c|}{ DPR } \\
\hline & Coefficient & Prob & Coefficient & Prob \\
\hline $\mathrm{C}$ & -1.1439 & $0.0000 * * *$ & -1.4383 & $0.0126^{* *}$ \\
\hline TAX & -0.3615 & $0.0000 * * *$ & 1.1887 & 0.2756 \\
\hline ROA & 0.3383 & $0.0000 * * *$ & 0.2691 & $0.0058 * * *$ \\
\hline DER & 0.0209 & $0.0000 * * *$ & 0.0244 & 0.1049 \\
\hline GROWTH & -0.0296 & 0.2427 & -0.0103 & 0.8731 \\
\hline Ln_ASSET & 0.0505 & $0.0000 * * *$ & 0.0416 & $0.0039 * * *$ \\
\hline $\mathrm{CG}^{-}$ & -0.0357 & 0.2296 & 0.1338 & 0.2918 \\
\hline FORG & 0.1290 & $0.0000 * * *$ & 0.1418 & 0.3064 \\
\hline FAM & & & 0.6251 & $0.0646^{*}$ \\
\hline TAX*FAM & & & -2.1085 & $0.0337 * *$ \\
\hline Adjusted R2 & \multicolumn{2}{|c|}{0.4660} & \multicolumn{2}{|c|}{0.0894} \\
\hline Prob(F-stat) & \multicolumn{2}{|c|}{$0.0000 * * *$} & \multicolumn{2}{|c|}{$0.0000 * * *$} \\
\hline
\end{tabular}

* significant at $10 \%$; * significant at $5 \%$; ** significant at $1 \%$

The results of the Model 2 testing (Table 4) confirming the second hypothesis of this study is supported. Companies with an ownership structure that results in a high dividend tax tend to avoid making dividend payments. A high dividend tax is generally considered to be a heavy burden due to the fact that dividends are paid from a company's retained earnings, which have already been taxed at the corporate income tax rate of $25 \%$. The cash that flows from a company to its shareholders through dividend payments is, therefore, sometimes considered to produce a decrease rather than an increase in shareholders' wealth.

\subsection{Family Ownership and Tax Avoidance}

Compared to other types of shareholders, family ownership is considered to be an effective organizational structure (Andres, 2008). Family firms have higher ownership concentration, lower diversification policies, long-term objectives, and greater reputational concerns (Chen et al., 2010). Moreover, families are involved in the management of the firms, which may affect their corporate decisions. The results of family ownership and tax avoidance through RPTs are presented in Table 5. The test of RPT-related sales (RPTS) and RPTA found that family ownership tends to weaken the relationship between shareholder tax burden and RPTs. The probability results for RPTL and RPTP were above $10 \%$, but the coefficient was still negative. These show consistent results. Overall, the results of this test prove that the third hypothesis of this study is supported.

Table 5: Tax Avoidance, RPT, and Family Ownership

\begin{tabular}{lcccccccc}
\hline \hline \multirow{2}{*}{ Variable } & \multicolumn{2}{c}{ RPTS } & \multicolumn{2}{c}{ RPTP } & \multicolumn{2}{c}{ RPTA } & \multicolumn{2}{c}{ RPTL } \\
\cline { 2 - 9 } & Coefficient & Prob & Coefficient & Prob & Coefficient & Prob & Coefficient & Prob \\
\hline C & -3.8575 & $0.0000^{* * *}$ & -0.8837 & $0.0000^{* * *}$ & -0.3765 & $0.0000^{* * *}$ & -0.3142 & $0.0000^{* * *}$ \\
TAX & 5.9799 & $0.0000^{* * *}$ & 1.3578 & $0.0000^{* * *}$ & 0.4270 & $0.0001^{* * *}$ & 0.2168 & $0.0000^{* * *}$ \\
ROA & 0.0168 & 0.5633 & -0.0407 & $0.0254^{* *}$ & 0.0129 & $0.0229 * *$ & -0.0106 & 0.1713 \\
DER & -0.0276 & $0.0010^{* * *}$ & 0.0231 & $0.0016^{* * *}$ & -0.0040 & $0.0059^{* * *}$ & 0.0266 & $0.0000^{* * *}$
\end{tabular}


An Analysis of Foreign Related Party Transactions and Dividend Payments

\begin{tabular}{lcccccccc}
\hline \multirow{2}{*}{ Variable } & \multicolumn{2}{c}{ RPTS } & \multicolumn{2}{c}{ RPTP } & \multicolumn{2}{c}{ RPTA } & \multicolumn{2}{c}{ RPTL } \\
\cline { 2 - 9 } & Coefficient & Prob & Coefficient & Prob & Coefficient & Prob & Coefficient & Prob \\
\hline GROWTH & -0.0320 & $0.0061^{* * *}$ & -0.0116 & 0.5245 & 0.0073 & $0.0807^{*}$ & -0.0138 & $0.0000^{* * *}$ \\
Ln_ASSET & 0.0754 & $0.0000^{* * *}$ & 0.0162 & $0.0000^{* * *}$ & 0.0100 & $0.0000^{* * *}$ & 0.0095 & $0.0000^{* * *}$ \\
CG & -0.0960 & $0.0022^{* * *}$ & 0.1158 & $0.0000^{* * *}$ & -0.0239 & $0.0004^{* * *}$ & -0.0097 & $0.0332^{* *}$ \\
FAM & 1.5191 & $0.0000^{* * *}$ & 0.0255 & 0.7512 & 0.1916 & $0.0000^{* * *}$ & 0.0047 & 0.8085 \\
TAX*FAM & $\mathbf{- 4 . 9 9 7 4}$ & $\mathbf{0 . 0 0 0 0 * * *}$ & $\mathbf{- 0 . 1 0 0 6}$ & $\mathbf{0 . 7 0 1 5}$ & $\mathbf{- 0 . 6 3 7 4}$ & $\mathbf{0 . 0 0 0 0 * * *}$ & $\mathbf{- 0 . 0 5 9 0}$ & $\mathbf{0 . 3 2 5 3}$ \\
Adjusted R2 & \multicolumn{2}{c}{0.3895} & \multicolumn{2}{c}{0.4057} & & 0.2484 & 0.3980 \\
Prob(F-stat) & \multicolumn{2}{c}{$0.0000^{* * *}$} & \multicolumn{2}{c}{$0.0000^{* * *}$} & & $0.0000^{* * *}$ & $0.0000^{* * *}$ \\
\hline \hline
\end{tabular}

* significant at $10 \% ; * *$ significant at $5 \% ; * * *$ significant at $1 \%$

In contrast to tax avoidance through risky and highly regulated RPTs, there tend to be no strict rules governing tax avoidance through dividend payments. For this reason, companies tend to avoid tax by using this mechanism, as already proven by the results of the fourth hypothesis testing. From Table 4, it can be seen that the result is indicating that family ownership tends to strengthen the negative relationship between the shareholder tax burden and dividend payments. This proves that family-owned companies tend to engage in tax avoidance by minimizing dividend payments that have a lower risk than RPTs. The test results prove that the fourth hypothesis of this study is supported.

\subsection{Discussion}

The present study found evidence of the tax avoidance practices conducted by companies through foreign RPTs to help their shareholders maximize their wealth and increase their after-tax investment return. Therefore, RPTs cannot be used to transfer corporate tax expenses since the same tax rate is now applied to all of the tax expenses to be paid. However, tax benefits will be obtained if the transactions are carried out among countries. In countries with high tax rates, especially high dividend tax rates, companies tend to avoid tax by shifting their profits. Profit shifting can result in a larger proportion of taxable income being taxed in countries with low tax rates, while a smaller proportion of taxable income is taxed in countries with high tax rates as a result of the RPTs carried out by companies. This research is consistent with Dischinger (2007) study, which show that companies take advantage of tax rate differences across countries and shift their global profits to low-tax countries or jurisdictions in order to avoid tax.

The results of the Hypothesis 2 testing found evidence that shareholder tax burden negatively affects dividend payments. This study found consistent results showing that a high shareholder tax burden leads to companies minimizing dividend payments in order to avoid tax. These results are consistent with tax preference theory suggesting that tax paid on dividends influences the behavior of shareholders. The results also accord with those obtained in studies carried out by Alzahrani \& Lasfer (2012), Blouin et al. (2011), Chen \& Gupta (2011), Hanlon \& Hoopes (2014), Wang \& Guo (2011), who found that dividend tax burden negatively affects dividend payments. Companies minimize their dividend payments to avoid high dividend tax. At the same time, companies are able to transfer some portion of their wealth to shareholders through RPTs as a substitute for dividends. These RPTs are used not only as a means of transferring wealth to shareholders but also as a means of avoiding tax through profit shifting (OECD, 2013). 
Companies usually seek to avoid tax after assessing the relative costs and benefits of such avoidance. The potential costs of tax avoidance may include increased legal and transaction costs (Rego \& Wilson, 2012; Wilson, 2009) and hostility toward the firm, including reputational damage among its various stakeholders (Lanis \& Richardson, 2012). Tax avoidance can also leave firms exposed to higher levels of political and regulatory risk, as well as social sanctions such as boycotts (Hoi et al., 2013). In the event that the tax avoidance is detected and the tax position is found to be unsupported, this can result in further financial penalties as well as the potential for increased damage to the firm's reputation (Desai \& Dharmapala, 2006; Hanlon \& Slemrod, 2009; Lanis \& Richardson, 2012). Managers implementing tax avoidance strategies are also personally exposed to the risk of penalties and fines, along with damage to their own reputations. As the risks associated with the detection of tax avoidance fall more heavily on the individual manager than on the firm itself, substantial compensation costs are required to offset the higher risks (Chen \& Chu, 2005). Family-owned companies are more likely to have a long investment horizon and a higher risk of tax avoidance (Chen et al., 2010) and, therefore, they tend to assess the relative costs and benefits of tax avoidance.

The present study found different results with regard to the two schemes of tax avoidance. Familyowned companies tend to avoid risky tax avoidance through RPTs and opt for a dividend minimization strategy. RPTs are strictly bound by tax regulation and capital markets, thus reducing the company's incentives to avoid taxes and increase the cost of tax avoidance by using this mechanism. On the contrary, dividend payments are not strictly regulated. Therefore, this type of strategy may reduce the costs of tax avoidance and result in the benefits of tax avoidance outweighing its costs.

Companies with higher family ownership are generally characterized by strong control over their management. Thus, the agency problem can be minimized. As a result, the role of dividends as a monitoring tool of the company becomes weak. With good control, family ownership can minimize the risk of expropriating the company's free cash flow, which can be undertaken if dividends are not distributed. Therefore, companies with family ownership will pay greater attention to corporate tax avoidance as opposed to dividend payments. This result confirms the mixed results on tax avoidance in family firms (Chen et al., 2010; Sari \& Martani, 2010).

\section{CONCLUSION}

The first result from this study is that shareholder tax burden has a positive effect on RPTs. This result indicates that the greater the tax burden, the greater the transactions of foreign related parties carried out by the company. This proves that the company is doing tax avoidance uses foreign RPTs. RPTs help companies to obtain tax benefits due to differences in the tax rates in Indonesia and abroad. By conducting foreign RPTs, companies can shift their profits from countries with high tax burdens to countries with lower tax burdens and receive tax benefits from the transactions.

The second result of this study is that shareholder tax burden has a negative effect on dividend payments. This research proves that in making dividend payments, companies have tax considerations and support tax preference theory (Brennan, 1970; Farrar \& Slewyn, 1967). Faced with high-tax-burden contexts, companies will choose to pay small dividends to avoid a large tax burden, which contrasts with their preferred course of action in a low-tax-burden scenario, where 
higher dividends are paid. Paying small dividends means that shareholders will avoid large dividend taxes as these are only imposed if dividends are distributed within the company. The results of this study support the findings of Sikka \& Willmott (2010) and Su et al. (2014), who demonstrated that tax burden leads to an increase in RPTs and a decrease in dividend payments.

The third result shows that family ownership tends to weaken the positive relationship between shareholder tax burden and RPTs. When family ownership is higher, the positive effect of shareholder tax burden on RPTs is lower. This proves that family-owned firms tend not to engage in tax avoidance practices compared to non-family firms. This results support those by Chen et al. (2010) who found that family firms tend not to practice tax avoidance because they have to defend their big names or avoid future tax problems. Family firms tend not to conduct party transactions related to taxation purposes because they have high tax risk considerations. Indonesia has a variety of strict regulations governing transfer pricing and a complete reporting system to prove the reasonableness of a related party's transaction prices. Consequently, for family firms that have a long investment horizon and a large amount of investment, there is considered to be a high level of risk to the business.

The fourth result from this study is that family ownership tends to strengthen the negative relationship between shareholder tax burden and dividend payments. When family ownership is high, the negative influence of shareholder tax burden on dividend payments becomes higher. This is because family firms have lower Type I than Type II agency conflicts. With lower Type I agency conflicts, the dividend function as a company's internal control also decreases; consequently, the company gives greater consideration to the tax burden than to dividend payments.

This research has several limitations. First, in Indonesia, different dividend tax rates apply to individual and corporate taxpayers, depending on the type of taxpayer and their share ownership percentage. However, the Indonesian rules stipulate that only shareholders that hold 5 percent or more of a company's stock are obliged to disclose their ownership. Therefore, it was not possible to estimate or measure the amount of dividend taxes paid by individual and corporate taxpayers with share ownership percentages of less than $5 \%$. Second, although the researchers closely supervised the measurement process in order to obtain valid data, the use of a checklist to measure corporate governance was susceptible to subjective error. Third, RPTs can be used to conduct both inward shifting and forward shifting. Therefore, companies may use RPTs to increase or decrease their benefits in Indonesia. Unfortunately, the researchers were not able to obtain detailed information regarding the outcomes of the RPTs for the companies in Indonesia.

\section{REFERENCES}

Allen, F., \& Michaely, R. (2003). Chapter 7 - Payout policy. In G.M. Constantinides, M. Harris, and R. Stulz (Eds.), Handbook of the economics of finance: Corporate finance (Vol. 1) (pp. 337-429). Amsterdam, Elsevier.

Alzahrani, M., \& Lasfer, M. (2012). Investor protection, taxation, and dividends. Journal of Corporate Finance, 18(4), 745-762.

Amiram, D., Andrew, M. B., \& Mary, M. F. (2019). Tax avoidance at public corporations driven by shareholder taxes: Evidence from changes in dividend tax policy. The Accounting Review, 94(5), 27-55. 
Anderson, R., \& Reeb, D. (2003). Founding-family ownership and firm performance: Evidence from the S\&P 500. Journal of Finance, 58(6), 1301-1328.

Andres, C. (2008). Large shareholders and firm performance: An empirical examination of founding-family ownership. Journal of Corporate Finance, 14(4), 431-445.

Ang, J. S., Coles, R. A., \& Wuh-Lin, J. (2000). Agency costs and ownership structure. Journal of Finance, 55(1), 81-107.

Arifin, Z. (2003). Masalah agensi dan mekanisme kontrol pada perusahaan dengan struktur kepemilikan terkonsentrasi yang dikontrol keluarga: Bukti dari perusahaan publik di Indonesia. Unpublished Dissertation, FEUI Graduate Program in Management.

Baker, R. W. 2005. Capitalism's Achilles Heel. New Jersey: John Wiley.

Berzins, J., Bøhren, B., \& Stacescu, B. (2019). Dividends and taxes: The moderating role of agency conflicts. Journal of Corporate Finance, 58(2019), 583-604.

Bhattacharya, S. (1979). Imperfect information, dividend policy, and 'the bird in the hand' fallacy. Bell Journal of Economics, 10(1), 259-270.

Blouin, J. L., Raedy, J. S., \& Shackelford, D. A. (2011). Dividends, share repurchases, and tax clienteles: Evidence from the 2003 reductions in shareholder taxes. The Accounting Review, 86(3), 887-914.

Brennan, M. (1970). Taxes, market valuation, and corporate financial policy. National Tax Journal 23(4), 417-427.

Zhuang, J., Edwards, D., Webb, D., \& Capulong, M. V. (2000). Corporate Governance and Finance in East Asia: A Study of Indonesia, Republic of Korea, Malaysia, Philippines, and Thailan: Volume One. Manila, Philippines: Asia Development Bank.

Chen, K. P, \& Chu, C. (2005). Internal control vs. external manipulation: A model of corporate income tax evasion. RAND Journal of Economics, 36(1), 151-164.

Chen, M. C., \& Gupta, S. (2011). An empirical investigation of the effect of imputation credits on remittance of overseas dividends. Journal of Contemporary Accounting \& Economics, 7(1), 18-30.

Chen, S., Chen, X., \& Cheng, Q, Shevlin, T. (2010). Are family firms more tax aggressive than non-family firms? Journal of Financial Economics, 95(1), 41-61.

Claessens, S., Djankov, S., \& Lang, L. H. P. (2000). The separation of ownership and control in East Asian corporations. Journal of Financial Economics, 58(1-2), 81-112.

Demsetz, H., \& Lehn, K. (1985). The structure of corporate ownership: Causes and consequences. Journal of Political Economy, 93(6), 1155-1177.

Desai, M. A., \& Dharmapala, D. (2006). Corporate tax avoidance and high-powered incentives. Journal of Financial Economics, 79(1), 145-179.

Desai, M. A., Foley, C. F., \& Hines, J. R. (2001). Repatriation taxes and dividend distortions. National Tax Journal, 54(4), 829-851.

Dischinger, M. (2007). Profit shifting by multinationals: Indirect evidence from European micro data. Munich Economics Discussion Papers, No. 2007-30, University of Munich.

Faccio, M., Lang, L. H. P., \& Young, L. (2001). Dividends and expropriation. American Economic Review, 91(1), 54-78.

Fama, E. F., \& French, K. R. (2001). Disappearing dividends: changing firm characteristics or lower propensity to pay. Journal of Financial Economics, 60(1),3-43.

Farrar, D. E \& Selwyn, L. L. (1967). Taxes, corporate financial policy and return to investors. National Tax Journal, 20(4), 444-454.

Foley, C. F., Hartzell, J. C., Titman, S., \& Twite, G. (2007). Why do firms hold so much cash? A tax-based explanation. Journal of Financial Economics, 86(3), 579-607. 
Gordon, M. (1963). Optimum investing and financing policy. Journal of Finance, 18(2), 264-272. Graham, J. R. (2003). Taxes and corporate finance: A review. The Review of Financial Studies, 16(4), 1075-1129.

Hanlon, M., \& Heitzman, S. (2010). A review of tax research. Journal of Accounting and Economics, 50(2), 127-178.

Hanlon, M., \& Hoopes, J. L. (2014). What do firms do when dividend tax rates change? An examination of alternative payout responses. Journal of Financial Economics, 114(1), $105-124$.

Hanlon, M., \& Slemrod, J. (2009). What does tax aggressiveness signal? Evidence from stock price reactions to news about tax shelter involvement. Journal of Public Economics, 93(1), $126-141$.

Hoi, C. K., Wu, Q., \& Zhang, H. (2013). Is corporate social responsibility (CSR) associated with tax avoidance? Evidence from irresponsible CSR activities. The Accounting Review, $88(6), 2025-2059$.

Jacob, J. (1996). Taxes and transfer pricing: Income shifting and the volume of intrafirm transfers. Journal of Accounting Research, 34(2), 301-312.

Jensen, M. C. (1986). Agency costs of free cash flow, corporate finance and takeover. American Economic Review, 76, 323-329.

Jian, M., \& Wong, T. J. (2004). Earnings management and tunnelling through related party transactions: Evidence from Chinese corporate groups. Paper No. 549EFA 2003 Annual Conference.

Johnson, S., LaPorta, R., Lopez-de-Silanes, F., \& Shleifer, A. (2000). Tunnelling. The American Economic Review, Vol. 90, No. 2, Papers and Proceedings of the One Hundred Twelfth Annual Meeting of the American Economic Association (May, 2000), 22-27.

Lanis, R., \& Richardson, G. (2012). Corporate social responsibility and tax aggressiveness: An empirical analysis. Journal of Account. Public Policy, 31(1), 86-108.

LaPorta, R., Lopez-de-Silanes, F., \& Shleifer, A. (1999). Corporate ownership around the world. Journal of Finance, 54(2), 471-517.

Mackie, R. (2001). Family ownership and business survival: Kirkcaldy, 1870-1970. Business History, 43(3), 1-32.

McClure, R., Lanis, R., Wells., P., \& Govendir, B. (2018). The impact of dividend imputation on corporate tax avoidance and controlling for outside director monitoring. Journal of Corporate Finance, 48, 492-514.

OECD. (2013). Addressing base erosion and profit shifting. Paris: OECD Publishing.

PriceWaterhouseCoopers. (2011). Transfer pricing and developing countries: Final Report. Retrieved from https://ec.europa.eu/taxation_customs/sites/taxation/files/docs/body/ transfer_pricing_dev_countries.pdf

Rego, S., \& Wilson, R. (2012). Equity risk incentives and corporate tax aggressiveness. Journal of Accounting Research, 50(3), 775-810.

Sari, D. K., \& Martani, D. (2010). Ownership characteristics, corporate governance, and tax aggressiveness. Paper in the 3rd Accounting \& The 2nd Doctoral Colloquium: Bridging the Gap between Theory, Research and Practice: IFRS Convergence and Application. Faculty of Economics, Universitas Indonesia.

Shleifer, A., \& Vishny, R. (1997). A survey of corporate governance. Journal of Finance, 52(2), 737-783.

Sikka, P., \& Willmott, H. (2010). The dark side of transfer pricing: Its role in tax avoidance and wealth retentiveness. Critical Perspectives on Accounting, 21(4), 342-356. 
Siregar, S. V., \& Utama, S. (2008). Type of earnings management and the effect of ownership structure, firm size, and corporate-governance practices: Evidence from Indonesia. The International Journal of Accounting, 43(1), 1-27.

$\mathrm{Su}$, Z. Q, Fung, H. G., Huang, D. S., \& Shen, C. H. (2014). Cash dividends, expropriation, and political connections: Evidence from China. International Review of Economics and Finance, 29, 260-272.

Sun, H. (1999). DFI, Foreign Trade and Transfer Pricing. Journal of Contemporary Asia, 29(3), 362-382.

Wang, C. F., \& Guo, Y. (2011). Do dividend tax cuts lead firms to increase dividends: Evidence from China. China Journal of Accounting Research, 4, 197-209.

Yeh, Y. H., Shu, P. G., \& Su, Y. H. (2012). Related-party transactions and corporate governance: The evidence from the Taiwan stock market. Pacific-Basin Finance Journal, 20(5), 755 776.

Zhang, H. (2008). Corporate governance and dividend policy: A comparison of Chinese firms listed in Hong Kong and in the Mainland. China Economic Review, 19, 437-459. 